Article

\title{
Targeted Isolation of Antioxidant Constituents from Plantago asiatica L. and In Vitro Activity Assay
}

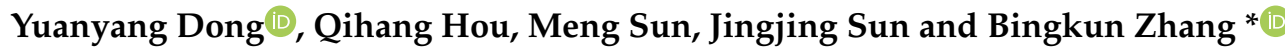 \\ State Key Laboratory of Animal Nutrition, Department of Animal Nutrition \& Feed Science, College of Animal \\ Science \& Technology, China Agricultural University, Beijing 100193, China; yuanyangdong@cau.edu.cn (Y.D.); \\ qihanghou1992@163.com (Q.H.); sunmengdk@163.com (M.S.); jingjingsun0816@126.com (J.S.) \\ * Correspondence: zhangbk@cau.edu.cn; Tel.: +86-010-6273-2712
}

Academic Editors: Francisco J. Barba, Zhenzhou Zhu, Jose M. Lorenzo and Fabienne Remize Received: 29 March 2020; Accepted: 13 April 2020; Published: 16 April 2020

\begin{abstract}
Plantago asiatica L. is widely distributed in Eastern Asia and a commonly used drug in China, Korea, and Japan for diuretic and antiphlogistic purposes. In this experiment, the present study was performed to isolate antioxidant molecules based on the DPPH scavenging activity assay and discover the bioactive compounds which contributed to performing the function of Plantago asiatica L. Each faction was chosen for further isolation guided by DPPH scavenging activity assay. Afterwards, two potential bioactive molecules, aesculetin and apigenin, were isolated for in vitro antioxidant activity in cells. Hydrogen-peroxide-induced oxidative stress led to decreased cell viability, impaired intercellular junction, and damage to the cell membrane and DNA. Furthermore, aesculetin ameliorated decreased cell viability induced by hydrogen peroxide via upregulation of antioxidant related genes, and apigenin also protected against $\mathrm{H}_{2} \mathrm{O}_{2}$ mainly by improving the glutathione (GSH) antioxidant system, such as increasing the activity of glutathione peroxidase (GPX), glutathione reductase (GR), and the ration of GSH/glutathione disulfide (GSSG). Above all, these findings suggest that aesculetin and apigenin may be bioactive compounds for antioxidant function in Plantago asiatica L.
\end{abstract}

Keywords: antioxidants; compound isolation; DPPH; Plantago asiatica L.; aesculetin; apigenin

\section{Introduction}

Oxidative stress is a consequence of an increased generation of free radicals and reduced antioxidant defense against free radicals [1]. Oxidative stress could result in DNA damage, and oxidative DNA adducts such as 8-oxodG have been involved in the tumorigenic process [2]. Antioxidant supplementation has become an increasingly popular practice to maintain body function [3]. However, several synthetic antioxidants such as butylated hydroxyanisole (BHA), butylated hydroxytoluene (BHT), and tert-Butylhydroquinone (TBHQ) have been reported to be harmful at high levels in animal experiments, and TBHQ is restricted in some countries, such as Canada and Japan [4]. TPlants are the richest sources of natural antioxidants. However, phytochemicals such as flavonoids are not easily absorbed, and higher concentration of flavonoids is more likely to be achieved in the lumen of the gastrointestinal tract where the flavonoids exert their antioxidant function [5]. The interaction between endogenous reactive oxygen species (ROS) and dietary antioxidants firstly takes place in the gastrointestinal tract [6]. There are several important aspects that should be carefully considered when it comes to the application of antioxidants, including their scavenging capacities, possible role in the endogenous antioxidant network, and their bio-viability [7].

Plantago asiatica L. is widely distributed in Eastern Asia and a commonly used drug in China, Korea, and Japan for diuretic and antiphlogistic purposes [8]. Phytochemical studies have shown that the Plantago genus contains a great number of natural products such as iridoids, flavonoids, tannins, 
triterpennes, saponins, and sterols [9]. Crude extracts of Asiatic plantain were found to significantly decrease DNA damage in lymphocytes caused by high-fat meals [10], but the effective molecules in the plantago were not identified. This study was designed to discover the bioactive molecules which contributed to performing the function of Plantago asiatica L. and exploring the possible mechanism.

\section{Results and Discussion}

\subsection{Targeted Isolation of Antioxidant Constituents from Plantago asiatica L. Based on DPPH Scanvenging Assay}

Seven extracts were obtained from superfine power of Plantago Asiatica L. Petroleum ether (15.61 g), dichloromethane (12.53 g), ethyl acetate (3.44 g) and ethyl acetate:methanol (10:1, v/v) gradient elution $(148.34 \mathrm{~g})$, ethyl acetate:methanol $(5: 1, v / v)(77.0 \mathrm{~g})$, ethyl acetate:methanol $(2: 1, v / v)(30.25 \mathrm{~g})$, and methanol (105.12 g) extracts were obtained through solid-liquid extraction. These solvents were chosen because they cover a wide range of polarities, allowing the fractionation of the substances. The different extract weights could be due to the characteristics and contents of the chemicals in the extracts. Additionally, ethyl acetate:methanol (10:1) produced the highest extraction yield of Plantago asiatica L., which suggested that most metabolites were moderately polar.

DPPH assay is one of the most commonly used methods due to its efficiency and simplicity. The free radical scavenging capacity of a sample is expressed as efficient concentration $\left(\mathrm{EC}_{50}\right)$, which is useful for comparing results due to its independence of the sample concentration [11]. The antioxidant activity of different extracts and fractions on DPPH radicals was tested, and their corresponding $\mathrm{EC}_{50}$ values are shown in Table 1. Ethyl acetate:methanol gradient elution showed the highest radical inhibitory activity with $\mathrm{EC}_{50} 0.086-0.117 \mathrm{mg} / \mathrm{mL}$, followed by ethyl acetate extract, methanol extract, and dichloromethane extract. In addition, as ethyl acetate:methanol (10:1) gave the highest yield, acetate:methanol (10:1) extract was chosen for further chromatographic separation, and six fractions, namely, F1-F6, were obtained based on the images on thin layer chromatography. Among the six fractions, $\mathrm{F} 4$ and $\mathrm{F} 6$ displayed the lowest $\mathrm{EC}_{50}$ values for the DPPH radical quench assay. Aesculetin (P1) was isolated from F4 via recrystallization.

Table 1. DPPH activity of different extracts of Plantago asiatica L. and its fractions.

\begin{tabular}{|c|c|c|c|}
\hline Samples & $\mathrm{EC}_{50}{ }^{1}(\mathrm{mg} / \mathrm{mL})$ & $\begin{array}{l}\text { Samples from Fractions of } \\
\text { E/M (10/1) Extract }\end{array}$ & $\mathrm{EC}_{50}(\mathrm{mg} / \mathrm{mL})$ \\
\hline Dichloromethane extract & $0.351 \pm 0.039^{d}$ & $\mathrm{~F} 1$ & $12.520 \pm 2.106^{\mathrm{f}}$ \\
\hline Ethyl acetate extract & $0.160 \pm 0.036^{\mathrm{c}}$ & $\mathrm{F} 2$ & $3.508 \pm 0.145^{\mathrm{e}}$ \\
\hline E/M (10/1) extract ${ }^{2}$ & $0.117 \pm 0.013^{\mathrm{ab}}$ & F3 & $0.499 \pm 0.038^{d}$ \\
\hline E/M (5/1) extract & $0.078 \pm 0.012^{\mathrm{a}}$ & F4 & $0.114 \pm 0.004^{\mathrm{b}}$ \\
\hline $\mathrm{E} / \mathrm{M}(2 / 1)$ extract & $0.086 \pm 0.016^{\mathrm{a}}$ & F5 & $0.230 \pm 0.010^{\mathrm{c}}$ \\
\hline Methanol extract & $0.153 \pm 0.021^{\mathrm{c}}$ & F6 & $0.064 \pm 0.009^{\mathrm{a}}$ \\
\hline$P$-value & $<0.001$ & $P$ value & $<0.001$ \\
\hline
\end{tabular}

\footnotetext{
${ }^{1} \mathrm{EC}_{50}$ : Concentration of substances (samples) discoloring $50 \%$ of the DPPH. ${ }^{2} \mathrm{E} / \mathrm{M}(\mathrm{a} / \mathrm{b})$ : the ratio of ethyl acetate to methanol is $\mathrm{a} / \mathrm{b}$ which was used for the extraction. Note: different superscripts in the same column differed significantly $(p<0.05)$.
}

The absorbance of different extracts between 0 and $1000 \mathrm{~nm}$ wavelength was scanned (Figure 1). Ethyl acetate and ethyl:methanol (10:1) extract showed a similar shape of absorbance pattern. Similarly, in another study aimed at characterizing the different polarity extracts obtained from Plantago major, methanol and ethyl acetate extracts had higher phenol concentration than dichloromethane and hexane, and only ethyl acetate had highest flavonoid concentration, including gallic acid, luteolin, quercetin, catechin, and galangin [12]. Thus, ethyl acetate extract was further analyzed. Apigenin (P2) was isolated from ethyl acetate extract. 


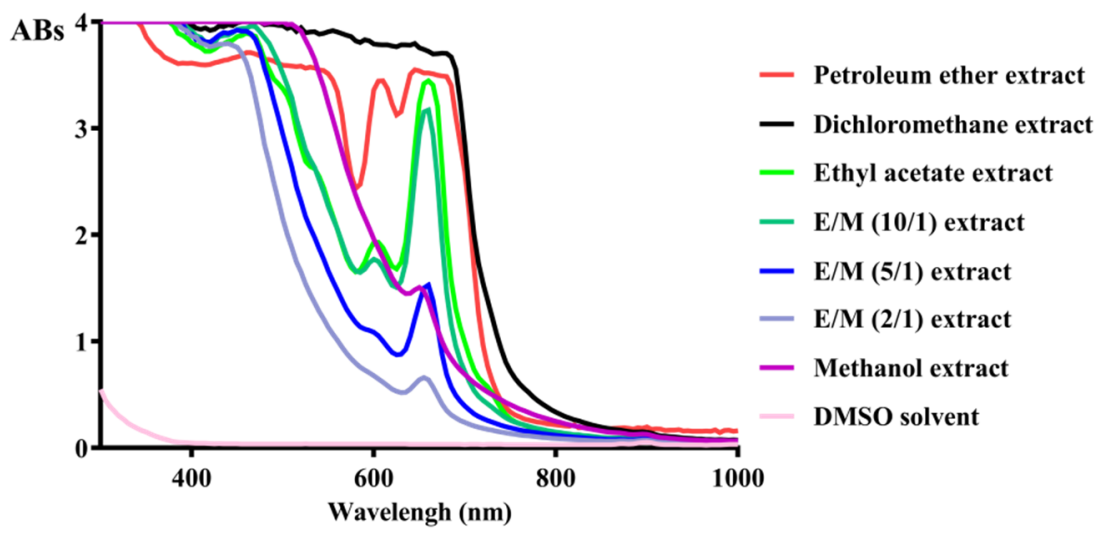

Figure 1. Wavelength scanning of different extracts.

\subsection{Structural Determination of the Isolated Compounds}

Four compounds were successfully isolated from the most active fractions of the Plantago Asiatica L. P1 was obtained as yellow needle-like crystals; mp. $268-270{ }^{\circ} \mathrm{C}$; ESI-MS m/z: $179[\mathrm{M}+\mathrm{H}]{ }^{+} ;{ }^{1} \mathrm{H}-\mathrm{NMR}$ (500 MHz, DMSO-d $)$ ) $7.85(1 \mathrm{H}, \mathrm{d}, J=9.5 \mathrm{~Hz}, \mathrm{H}-4), 6.15(1 \mathrm{H}, \mathrm{d}, J=9.5 \mathrm{~Hz}, \mathrm{H}-3), 6.97(1 \mathrm{H}, \mathrm{s}, \mathrm{H}-5)$, $6.74(1 \mathrm{H}, \mathrm{s}, \mathrm{H}-8), 10.20(1 \mathrm{H}, \mathrm{s}, \mathrm{OH}), 9.39(1 \mathrm{H}, \mathrm{s}, \mathrm{OH})$. According to the published literature, the above data were consistent with the report, and compound P1 was identified to be aesculetin [13]. P2 was isolated as a faint yellow powdered crystal, mp. $347-348{ }^{\circ} \mathrm{C}$. ESI-MS $m / z: 271[\mathrm{M}+\mathrm{H}]^{+} ;{ }^{1} \mathrm{H}-\mathrm{NMR}$ $\left(500 \mathrm{MHz}, \mathrm{DMSO}-d_{6}\right)$ 8:12.96 (1H, s, 5-OH), $7.92\left(2 \mathrm{H}, \mathrm{d}, J=9.0 \mathrm{~Hz}, \mathrm{H}-2^{\prime}, 6^{\prime}\right), 6.92\left(2 \mathrm{H}, \mathrm{d}, J=9.0 \mathrm{~Hz}, \mathrm{H}-3^{\prime}\right.$, $\left.5^{\prime}\right), 6.78(1 \mathrm{H}, \mathrm{s}, \mathrm{H}-3), 6.48(1 \mathrm{H}, \mathrm{d}, J=2.0 \mathrm{~Hz}, \mathrm{H}-8), 6.19(1 \mathrm{H}, \mathrm{d}, J=2.0 \mathrm{~Hz}, \mathrm{H}-6)$. From these observations and through comparison with literature NMR data [14], we concluded that P2 was apigenin.

\subsection{Hydrogen-Peroxide-Induced Oxidative Stress in Caco-2 Cells}

Hydrogen peroxide $\left(\mathrm{H}_{2} \mathrm{O}_{2}\right)$ above $150 \mu \mathrm{M}$ significantly decreased cell viability, and $1000 \mu \mathrm{M}$ $\mathrm{H}_{2} \mathrm{O}_{2}$ further reduced cell viability to about $50 \%$ (Figure $2 \mathrm{~A}$ ). Similar results that $1 \mathrm{mM} \mathrm{H}_{2} \mathrm{O}_{2}$ treated for $6 \mathrm{~h}$ significantly reduced the cell viability of Caco-2 were observed [15]. Additionally, treatments with $0.8 \mathrm{mM} \mathrm{H}_{2} \mathrm{O}_{2}$ for $24 \mathrm{~h}$ led to increased release of lactate dehydrogenase (LDH), an indicator of cell membrane injury in IPEC-J2 cells [16]. LDH is a stable intracellular enzyme which can be released into the cell culture medium upon damage of the plasma membrane [17]. The leakage of $\mathrm{LDH}$ under treatment of $\mathrm{H}_{2} \mathrm{O}_{2}$ was measured in this study (Figure 2B). A total of 250-2000 $\mu \mathrm{M} \mathrm{H}_{2} \mathrm{O}_{2}$ significantly increased the LDH level in the culture media, which indicated that $\mathrm{H}_{2} \mathrm{O}_{2}$ can lead to cell membrane damage. Transepithelial electrical resistance (TEER) was regarded as an indicator of monolayer integrity and paracellular permeability [18]. In Figure 2C, 250-1000 $\mu \mathrm{M} \mathrm{H}_{2} \mathrm{O}_{2}$ decreased the TEER after $4 \mathrm{~h}$ treatment of hydrogen peroxide. Consistent with our experiments, a previous study showed that treatment of $500 \mu \mathrm{M} \mathrm{H}_{2} \mathrm{O}_{2}$ for $6 \mathrm{~h}$ also caused a significant decrease in TEER in Caco-2 cell monolayers [19]. ROS can be tumorigenic by inducing DNA damage, leading to a genetic lesion that initiates tumorigenicity [20]. Moreover, as shown in Figure 2D, $1000 \mu \mathrm{M} \mathrm{H}_{2} \mathrm{O}_{2}$ significantly upregulated the tail DNA percentage, tail moment, and olive tail moment, which were measured by comet assay, as shown in Figure 2E. Similarly, in another study, DNA damage as measured by comet assay was significantly high at concentration $>100 \mu \mathrm{M} \mathrm{H}_{2} \mathrm{O}_{2}$ compared to that of the control in Caco-2 cells [21]. Above all, $\mathrm{H}_{2} \mathrm{O}_{2}$ treatment led to decreased cell viability, which may result from impaired cell membranes, damaged intercellular junctions, and DNA damage. Concentration of $1000 \mu \mathrm{M} \mathrm{H}_{2} \mathrm{O}_{2}$ was selected for the following study to induce cell oxidative stress. 

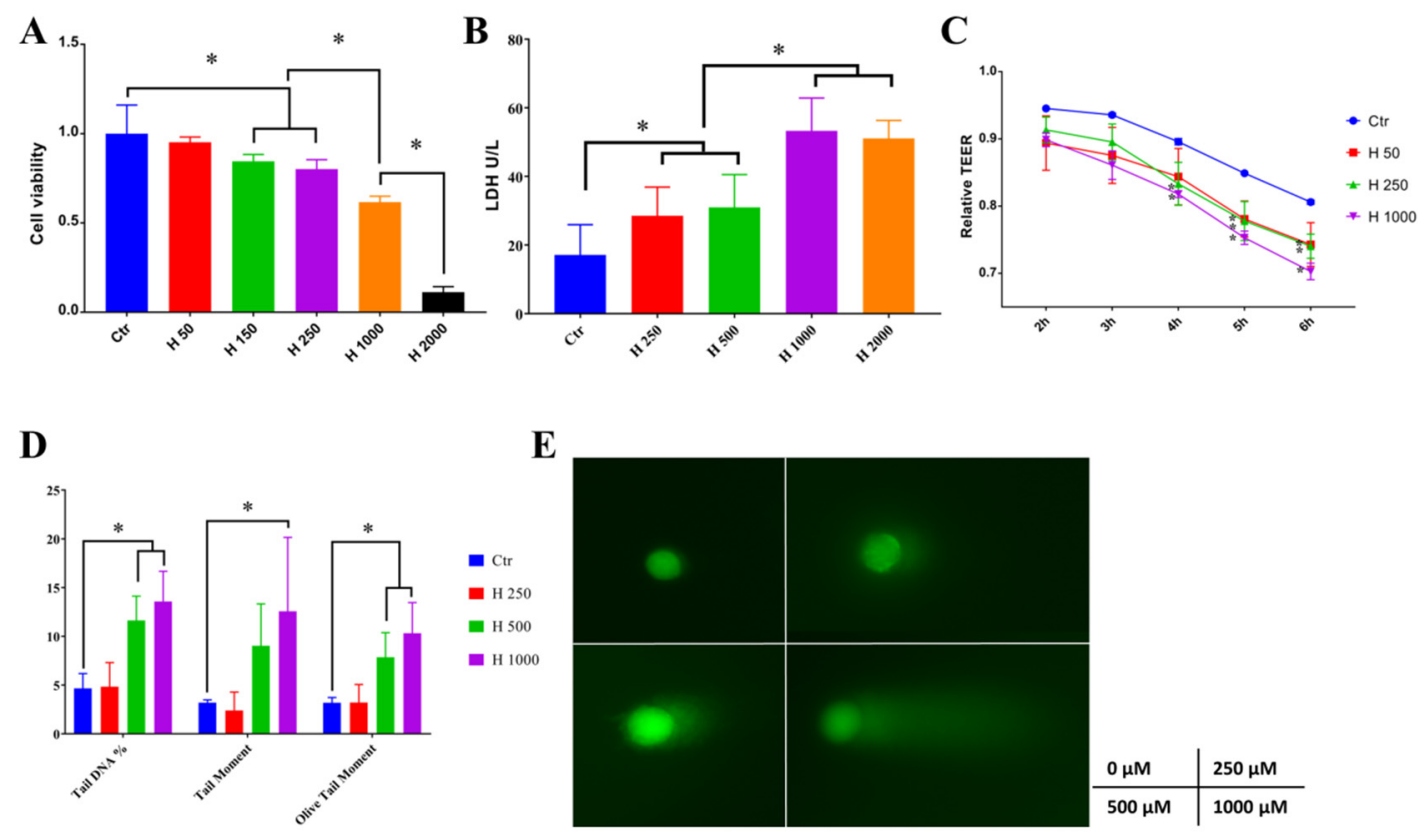

Figure 2. Establishment of a hydrogen peroxide-induced oxidative stress Caco-2 cell model. (A) Hydrogen peroxide significantly decreased cell viability. (B) Hydrogen peroxide above $250 \mu \mathrm{M}$ significantly increased the lactate dehydrogenase (LDH) leakage from the cell. (C) Transepithelial electrical resistance (TEER) of Caco-2 was significantly decreased by hydrogen peroxide. (D,E) Tail DNA, tail moment, and olive tail moment was significantly unregulated by hydrogen peroxide, which were measured by comet assay $\left({ }^{*} p<0.05\right)$.

\subsection{Aesculetin and Apigenin Ameliorated Oxidative Damages Induced by Hydrogen Peroxide through Different Mechanisms}

Aesculetin significantly ameliorated the decreased cell viability caused by hydrogen peroxide (Figure 3A). Nuclear factor-E2-related factor 2 (Nrf2) is a transcription factor that is sensitive to oxidative stress and promotes the transcription of a wide variety of antioxidant genes, such as superoxide dismutase (SOD), catalase (CAT), glutathione S-transferase (GST), heme oxygenase (HO-1), gamma-glutamine cysteine synthase ( $\gamma$-GCS), and glutathione peroxidase (GPX) [22]. In our study, aesculetin at 100 and $300 \mu \mathrm{g} / \mathrm{mL}$ dramatically enhanced the mRNA expression of Nrf2, and its downstream genes SOD, CAT, and GCS compared to $\mathrm{H}_{2} \mathrm{O}_{2}$ treatment, while $\mathrm{H}_{2} \mathrm{O}_{2}$ treatment only slightly increased the mRNA of Nrf2 (Figure 3B). Several kinds of natural and synthetic compounds were reported to activate the Nrf2/Keap1/ARE system: (1) diphenols, quinones, and phenylenediamines; (2) natural components from plants, such as curcumin, resveratrol, luteolin, and quercetin; (3) hydrogen peroxide, 4-tert-butyl hydrogen peroxide; and (4) components rich in trace elements such as selenium, arsenic, and other substances [23]. Therefore, aesculetin with an ortho-hydroxyl structure can further activate Nrf2 and enhance the transcription of SOD, CAT, and GPX, which was observed in this experiment. $\mathrm{H}_{2} \mathrm{O}_{2}$ significantly improved the activity of glutathione peroxidase but inhibited the activity of glutathione reductase (GR) (Figure 3C,D). However, aesculetin did not show any significant effect on the activity of GPX and GR. 
A

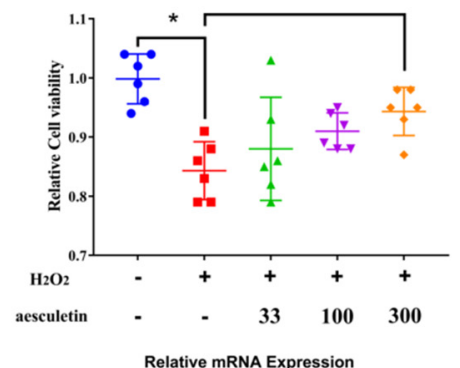

B

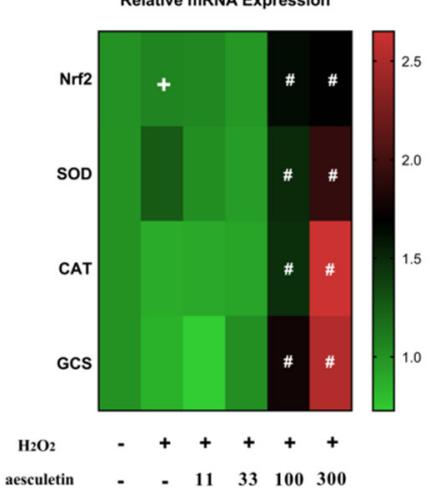

C

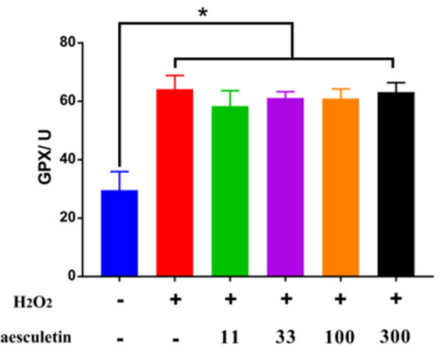

D

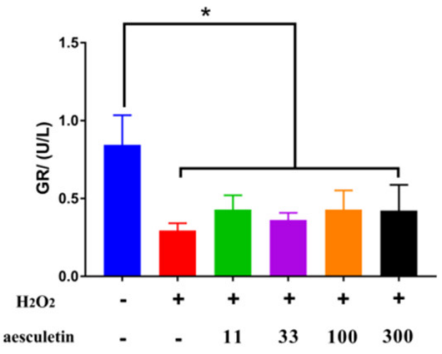

Figure 3. Aesculetin ameliorated decreased cell viability induced by hydrogen peroxide via upregulation of antioxidant related genes. (A) Aesculetin significantly ameliorated the decreased cell viability caused by hydrogen peroxide. (B) $\mathrm{H}_{2} \mathrm{O}_{2}$ slightly upregulated the mRNA expression of Nrf2 but 100 and $300 \mu \mathrm{g} / \mathrm{mL}$ aesculetin dramatically increased the gene expressions of Nrf2, superoxide dismutase (SOD), catalase (CAT), and glutamyl cysteine synthetase (GCS) compared to $\mathrm{H}_{2} \mathrm{O}_{2}$ treatment. (C,D) $\mathrm{H}_{2} \mathrm{O}_{2}$ treatment significantly improved the activity of glutathione peroxidase but suppressed the activity of glutathione reductase. ( $p<0.05,{ }^{+} p<0.05$ vs. control, ${ }^{\#} p<0.05$ vs. $\mathrm{H}_{2} \mathrm{O}_{2}$ treatment).

Apigenin is a flavone that exists widely in many fruits and vegetables such as onions, oranges, and tea [24]. Apigenin at 125 and $250 \mu \mathrm{g} / \mathrm{mL}$ significantly ameliorated the decreased cell viability caused by hydrogen peroxide (Figure $4 \mathrm{~A}$ ). In the hydrogen-peroxide-induced oxidative stress model in the MC3T3-E1 mouse osteoblastic cell line, pretreatment of cells with apigenin attenuated the reduced cell viability and upregulated the gene expression of SOD1, SOD2, and GPX [24]. However, apigenin reversed the increased mRNA expression of $\mathrm{Nrf} 2$ and GCS caused by $\mathrm{H}_{2} \mathrm{O}_{2}$ and decreased the mRNA expression of CAT but enhanced the transcription level of SOD (Figure 4B). SOD catalyzed the dismutation of $\mathrm{O}_{2}{ }^{-}$to $\mathrm{H}_{2} \mathrm{O}_{2}$ [25]. Additionally, apigenin further increased the activity of GPX, which was slightly enhanced by $\mathrm{H}_{2} \mathrm{O}_{2}$ (Figure 4C). Different changes of GPX and CAT activity were observed in a similar cell model. GPX activity increased with higher $\mathrm{H}_{2} \mathrm{O}_{2}$ concentration, while CAT activity remained constant at different $\mathrm{H}_{2} \mathrm{O}_{2}$ treatments, which indicated that GPX was more active than CAT in scavenging $\mathrm{H}_{2} \mathrm{O}_{2}$ [21]. CAT played an important role as a primary defense enzyme against $\mathrm{H}_{2} \mathrm{O}_{2}$ at a low concentration but with a higher concentration of $\mathrm{H}_{2} \mathrm{O}_{2}$, GPX worked as a primary defense enzyme against oxidative damage [21]. Moreover, apigenin reversed the decreased activity of GR caused by $\mathrm{H}_{2} \mathrm{O}_{2}$ (Figure 4D). GPX and GR are two key enzymes involved in the glutathione (GSH) redox cycle, where GPX uses GSH to reduce organic peroxide and $\mathrm{H}_{2} \mathrm{O}_{2}$, and GR reduces glutathione disulfide (GSSG) to GSH in a nicotinamide adenine dinucleotide phosphate (NADPH)-dependent manner [25]. Since GPX and GR activity were increased by apigenin compared to the $\mathrm{H}_{2} \mathrm{O}_{2}$ treated group, intracellular GSH level was examined in the following study. 
A

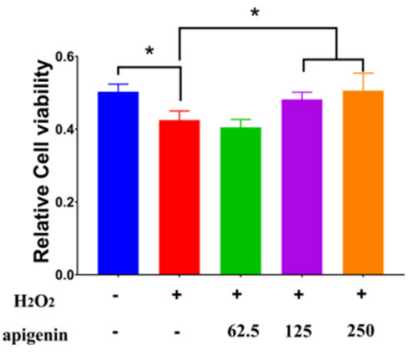

B

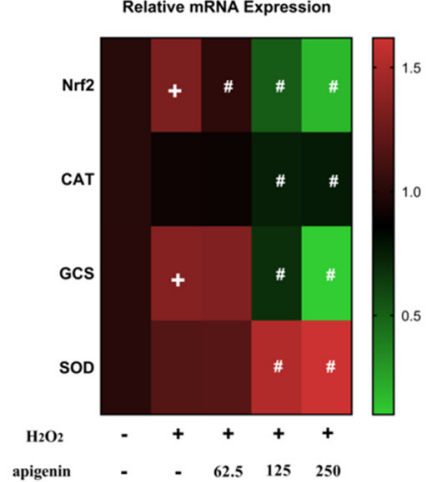

C

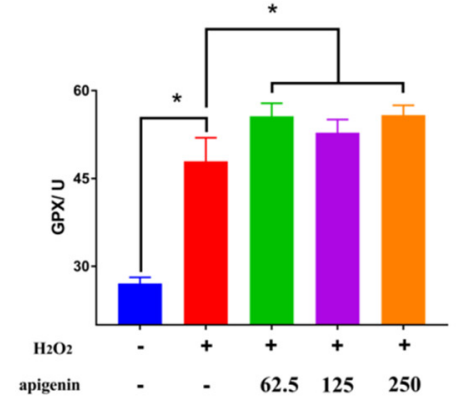

D

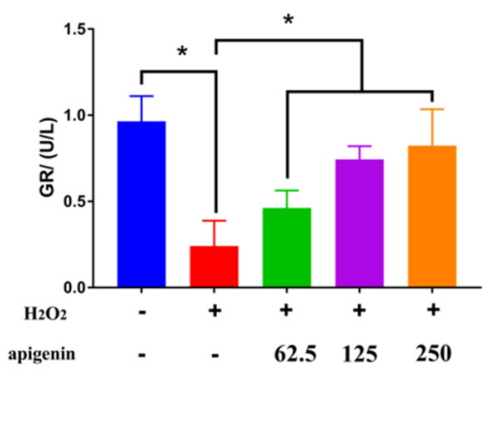

Figure 4. Apigenin ameliorated decreased cell viability induced by hydrogen peroxide through enhancement of glutathione peroxidase (GPX) and glutathione reductase (GR). (A) Apigenin ameliorated decreased cell viability induced by hydrogen peroxide. (B) Modulation of antioxidant related genes was observed in apigenin treatment. (C,D) Apigenin reversed the inhibition of enzyme activities of GPX and GR ( $\left(^{*} p<0.05,{ }^{+} p<0.05\right.$ vs. control, ${ }^{\#} p<0.05$ vs. $\mathrm{H}_{2} \mathrm{O}_{2}$ treatment). Glutathione (GSH) is at the heart of one of the most important cellular antioxidant systems and capable of scavenging reactive oxygen species (ROS) and contributes to maintaining redox homoeostasis [26]. $\mathrm{H}_{2} \mathrm{O}_{2}$ significantly decreased the total GSH, which was further decreased by apigenin (Figure 5A). The biosynthesis of GSH is catalyzed by the action of two ATP-dependent enzymes, $\gamma$-glutamylcysteine synthetase ( $\gamma$-GCS) and glutathione synthase (GS), and GCS catalyzes the formation of $\gamma$-glutamyl-cysteine from glutamate and cysteine in the presence of ATP, which is the rate-limiting step in biosynthesis [27]. Similarly oxidized dimer of GSH (GSSG) decreased by $\mathrm{H}_{2} \mathrm{O}_{2}$ was further inhibited by apigenin (Figure 5B). The decreased total GSH may have resulted from the downregulation of GCS transcription. In cells, GSSG can be regenerated by GR, and GR is responsible for maintaining the supply of reduced GSH [26]. The ratio of GSH/GSSG has been regarded as an index of oxidative stress [28]. However, apigenin alleviated the decreased ration of GSH to GSSH caused by $\mathrm{H}_{2} \mathrm{O}_{2}$ (Figure $5 \mathrm{C}$ ), which was related to the increased mRNA expression of GR.

A

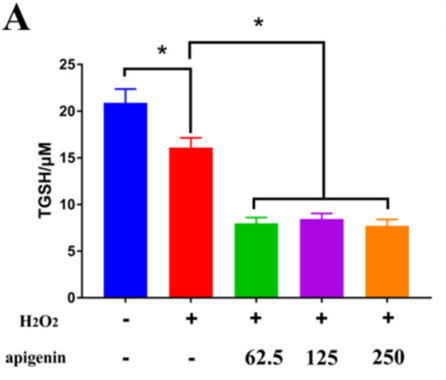

B

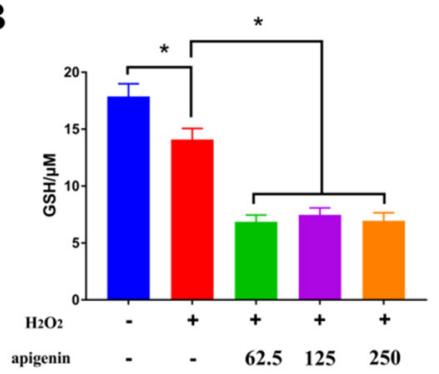

C

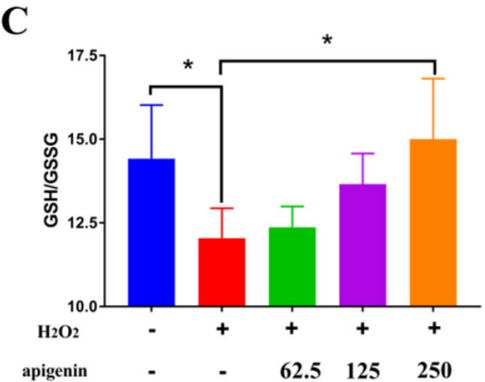

Figure 5. Modulation of apigenin on the total GSH (A), reduced GSH (B), and the ratio of GSH to GSSG (C) $\left({ }^{*} p<0.05\right)$. 


\section{Materials and Methods}

\subsection{Material and Chemicals}

Plantago asiatica L. was purchased from Tongrentang Chinese Medicine-Since 1669 (Beijing, China). Petroleum ether, dichloromethane, ethyl acetate, and methanol were analytically pure and obtained from Beijing Chemical Industry Group Co. LTD (Beijing, China). The 2,2-diphenyl-1-picrylhydrazyl (DPPH) was provided by Sigma-Aldrich LLC (St. Louis, Missouri, USA). Thin-layer chromatography GF254 and silica gel column chromatography (80-100 mesh, 100-200 mesh, and 200-300 mesh) were purchased from Qindao Haiyang Chemical Industry (Qingdao, China). Solution of 5\% sulfuric acid ethanol was used as chromogenic agent. Aesculetin and apigenin (purity $>98 \%$ ) were purchased from Aladdin Biochemical Technology Co. LTD (Shanghai, China).

\subsection{Free Radical Scavenging Ability on DPPH and Absorbance Spectrum}

DPPH scavenging activity was determined according to the method reported by BrandWilliams [29] with some modifications. A total of $25 \mathrm{mg}$ DPPH was dissolved in $50 \mathrm{~mL} 80 \%$ ethanol as stock solution. DPPH stock solution was diluted with $80 \%$ ethanol at ratio of 1:2 (v/v) before measurement to prepare the work solution of DPPH. Each sample was diluted in a gradient ratio of 1:1 to 11 gradients. After dilution, $100 \mu \mathrm{L}$ solution at all concentrations and $80 \%$ ethanol (as blank) was added into flat bottom 96-well plate. Then, the $100 \mu \mathrm{L}$ DPPH work solution was added to each well, and the absorbance was determined at $517 \mathrm{~nm}$ after reaction at room temperature in the dark for $30 \mathrm{~min}$. The eliminate percentage (E\%) of $\mathrm{DPPH}$ at the steady state was determined using the following equation: $\mathrm{E} \%=1-\left(\mathrm{Abs}\right.$ blank $-\mathrm{Abs}$ sample)/Abs blank. $\mathrm{EC}_{50}$, which is the concentration of substances (samples) discoloring 50\% of the DPPH, was calculated by GraphPad Prism 5 (Version 7.04, Graphpad Software, San Diego, CA, USA, www.graphpad.com).

The absorbance of different extracts in the same concentration between 0 and $1000 \mathrm{~nm}$ wavelength was scanned by Microplate Reader (Spectra Max i3x, Molecular Devices, San Jose, CA, USA).

\subsection{Cell Culture and $\mathrm{H}_{2} \mathrm{O}_{2}$ Exposure}

Caco-2 cells were purchased from the Institute of Animal Science of CAAS (Beijing, China). Caco-2 cells were cultured in DMEM supplemented with $10 \% \mathrm{FBS}, 1 \%$ penicillin, and streptomycin at $37^{\circ} \mathrm{C}$ in humidified air containing $5 \% \mathrm{CO}_{2}$.

Caco- 2 cells $\left(2 \times 10^{4} /\right.$ well) grown for $24-48 \mathrm{~h}$ were allowed to attach to the culture plate before being pretreated with aesculetin or apigenin overnight. Then cells were treated with $1 \mathrm{mM} \mathrm{H}_{2} \mathrm{O}_{2}$ in DMEM without FBS for $2 \mathrm{~h}$. The culture media and cells were collected for the further measurements.

\subsection{Cell Viability and LDH Assay}

Cell viability was measured using a CCK-8 kit in accordance with the manufacturer's instructions (Dojindo, Kumamoto, Japan). Briefly, Caco- 2 cells were seeded in a 96-well plate at $2 \times 10^{4}$ cell per well and cultured overnight. Cells were pretreated with the same compounds isolated from Plantago asiatica L. for $18 \mathrm{~h}$ after plate attachment. Then, cells were then treated with $\mathrm{H}_{2} \mathrm{O}_{2}$ for $2 \mathrm{~h}$. The culture media was collected for LDH (lactate dehydrogenase) assay and replaced by $200 \mu \mathrm{L}$ DMEM supplemented with $10 \%$ CCK-8 per well and cultured at $37^{\circ} \mathrm{C}$ for $2 \mathrm{~h}$. Afterward, the absorbance was measured at $450 \mathrm{~nm}$ on a Microplate Reader (Spectra Max i3x, Molecular Devices, USA). The LDH activity in the cultural media was measured based on the reaction between LDH and lactic acid, which led to the generation of pyruvic acid, and pyruvic acid could become brown in alkaline environments with 2,4-dinitrophenylhydrazine via a commercial kit obtained from Nanjing Jiancheng Bioengineering Institute (Nanjing, China). 


\subsection{Measurement of Intercellular Transmembrane Resistance (TEER)}

TEER was measured based on the method reported by Shao et al. [30]. Briefly, Caco-2 cells grown on a Transwell filter and transepithelial electrical resistance were monitored daily before differentiation by use of a Milicell Electrical Resistance System-2 (Millipore Corp., Bedford, MA, USA) and expressed as $\Omega \times \mathrm{cm}^{2}$.

\subsection{Comet Assay}

Comet assay, namely, single-cell gel electrophoresis assay, is a relatively convenient and sensitive technique for the analysis of DNA breakage in individual cells and commonly used for the investigation of antioxidants in intervention studies. The procedures of DNA strand breaks were determined by comet assay, according to the method reported by Fernández-Blanco with some modifications [31]. Briefly, Caco- 2 cells $\left(2.0 \times 10^{5}\right.$ cells/well $)$ were seeded in 6-well plate and grew for $42 \mathrm{~h}$. Then cells were treated with $0-1 \mathrm{mM} \mathrm{H}_{2} \mathrm{O}_{2}$ for $2 \mathrm{~h}$ followed by being suspended in prewarmed low-melting-point agarose. Additionally, suspension was rapidly transferred to precoated slide with agarose and covered with a coverslip. Coverslip was removed after gelling for $10 \mathrm{~min}$ at $4{ }^{\circ} \mathrm{C}$, and a second low-melting-point agarose was added with gelatinization for $10 \mathrm{~min}$ at $4{ }^{\circ} \mathrm{C}$. Then. slides were put into lysis buffer $(2.5 \mathrm{M}$ $\mathrm{NaCl}, 100 \mathrm{mM}$ Na-EDTA, $10 \mathrm{mM}$ Tris, $250 \mathrm{mM} \mathrm{NaOH}, 10 \%$ DMSO, and 1\% Triton X-100) for $30 \mathrm{~min}$ at $4{ }^{\circ} \mathrm{C}$ and incubated in the fresh electrophoresis buffer ( $300 \mathrm{mM} \mathrm{NaOH}, 1 \mathrm{mM} \mathrm{Na}-\mathrm{EDTA}$ ) for $20 \mathrm{~min}$ to unwind the DNA after removing the residual lysate. After electrophoresis for $40 \mathrm{~min}(25 \mathrm{~V}, 300 \mathrm{~mA})$, slides were washed with neutralization buffer (0.4 M Tris, $\mathrm{pH} 7.5)$ three times. Slides were stained with $500 \mu \mathrm{L}$ PI $(20 \mu \mathrm{g} / \mathrm{mL})$, covered with a coverslip, and kept at $4{ }^{\circ} \mathrm{C}$ for $40 \mathrm{~min}$. Slides were visualized under a fluorescence microscope (Lica universal microscope). At least 30 randomly selected single cells were analyzed by Comet Assay Software Project (http://casplab.com/). The DNA damage in cells was expressed as a percentage of total DNA content in the tail, tail moment, and olive tail moment (tail moment $=$ tail length $\times$ tail DNA; tail moment $=$ TailDNA $\% \times($ TailMeanX - HeadMeanX $)$, equaling to ((percent of DNA in the tail) $\times$ (distance between the center of gravity of DNA in the tail and the of center of gravity of DNA in the head in $\mathrm{x}$-direction)).

\subsection{Transcription Levels Analysis by RT-PCR}

Briefly, cells seeded in a 6-well plate after treatments were collected. Total RNA extraction was carried out by an Eastep Super Total RNA Extraction Kit (Peomaga Co., Shanghai, China). RNA quantity was measured by Nanodrop at 260 and $280 \mathrm{~nm}$. Then, total RNA was reverse-transcribed into cDNA through a PrimeScripTMRT reagent Kit with gDNA Eraser (Perfect Real Time) (Takara, Japan), and gene expression was determined by SYBR Premix Ex TaqTM (Tli RNaseH Plus, Takara, Japan) in accordance with manufacturer's protocol. Gene primers are reported in Table 2, and 2- $\Delta \Delta \mathrm{Ct}$ was calculated to express the gene expression level.

Table 2. Primer for RT-PCR amplification.

\begin{tabular}{|c|c|c|c|}
\hline Gene & & & Note \\
\hline$\beta$-actin & Forward Primer & GGATGCAGAAGGAGATCACTG & NM_001498.4 \\
\hline \multirow{2}{*}{ Nrf2 } & Forward Primer & AAACCAGTGGATCTGCCAAC & \multirow{2}{*}{ NM_001101.5 } \\
\hline & Revers Primer & GCAATGAAGACTGGGCTCTC & \\
\hline \multirow{2}{*}{ SOD } & Forward Primer & GTAATGGACCAGTGAAGGTGT & \multirow{2}{*}{ NM_000454.5 } \\
\hline & Revers Primer & CAATTACACCACAAGCCAAACG & \\
\hline \multirow{2}{*}{ CAT } & Forward Primer & CGTGCTGAATGAGGAACAGA & \multirow{2}{*}{ NM_001752.4 } \\
\hline & Revers Primer & AGTCAGGGTGGACCTCAGTG & \\
\hline \multirow{2}{*}{ GCS } & Forward Primer & GGCGATGAGGTGGAATACAT & \multirow{2}{*}{ M90656.1 } \\
\hline & Revers Primer & CCTGGTGTCCCTTCAATCAT & \\
\hline
\end{tabular}




\subsection{Measurements of Antioxidant Enzyme}

Glutathione peroxidase (GPX) and glutathione reductase (GR) were analyzed using a commercial kit (Nanjing Jiancheng Bioengineering Institute, China). Briefly, the activity of GPX was determined based on the reaction between GSH and disulfide dinitrobenzoic acid (DNTB). Activity of GR was detected via changes of NADPH along with transformation of GSSG to GSH under catalysis of GR. Total GSH and reduced GSH were determined using a commercial GSH and GSSG kit (Beyotime biotechnology Co., Beijing, China). Briefly, DNTB and NADPH were converted to 5'-thionitrobenzoic acid (TNB) and NADP ${ }^{+}$under catalysis by GR with GSSG and GSH. There was a positive correlation between the generation of TNB and total glutathione content.

\subsection{Statistical Analysis}

Statistical analysis was carried out using SPSS version 15 and data were expressed as mean \pm SD. The differences between groups were analyzed with one-way ANOVA, and $p<0.05$ was considered statistically significant.

\section{Conclusions}

The results of the present study have conclusively indicated that aesculetin and apigenin isolated from Plantago asiatica L. could ameliorate the Caco-2 cell damage caused by $\mathrm{H}_{2} \mathrm{O}_{2}$. Aesculetin protected cell from oxidative damage by activating Nrf-2 and its downstream genes such as SOD, CAT, and GCS and increasing the activity of GPX to enhance the intracellular antioxidant defense system. Apigenin exerted its protection against $\mathrm{H}_{2} \mathrm{O}_{2}$ mainly by improving the GSH antioxidant system, such as increasing the activity of GPX, GR, and the ration of GSH/GSSG. These findings suggest that aseculetin and apigenin may be bioactive substances for antioxidant function in Plantago asiatica $\mathrm{L}$.

Author Contributions: Conceptualization, Y.D., Q.H., and B.Z.; Formal analysis, M.S.; Funding acquisition, B.Z.; Investigation, Y.D.; Methodology, Y.D. and Q.H.; Project administration, B.Z.; Software, J.S.; Writing-original draft, Y.D.; Writing - review and editing, Y.D. and B.Z. All authors have read and agreed to the published version of the manuscript.

Funding: This research was funded by the National Key R\&D Program of China (2017YFE0129900) and the Funding of Young Talent Supporting Program of the College of Animal Science and Technology of the China Agricultural University Education Foundation (2017DKA002).

Acknowledgments: Our thanks go to Natural Medicine Chemistry Research Center, Peking Union Medical College Institute of Medical Plant Development, especially Bo Song who offered the methods for identification and isolation of the phytochemicals.

Conflicts of Interest: The authors declare no conflict of interest.

\section{References}

1. Poljsak, B.; Šuput, D.; Milisav, I. Achieving the balance between ROS and antioxidants: When to use the synthetic antioxidants. Oxid. Med. Cell. Longev. 2013, 2013, 1-11. [CrossRef]

2. Wirtz, S.; Popp, V.; Kindermann, M.; Gerlach, K.; Weigmann, B.; Fichtner-Feigl, S.; Neurath, M.-F. Chemically induced mouse models of acute and chronic intestinal inflammation. Nat. Protoc. 2017, 12, 1295-1309. [CrossRef]

3. Kurutas, E.-B. The importance of antioxidants which play the role in cellular response against oxidative/nitrosative stress: Current state. Nutr. J. 2015, 15, 71. [CrossRef]

4. Wang, H.; Liu, Y.-M.; Qi, Z.-M.; Wang, S.-Y.; Liu, S.-X.; Li, X.; Wang, H.-J.; Xia, X.C. An Overview on Natural Polysaccharides with Antioxidant Properties. Curr. Med. Chem. 2013, 20, 2899-2913. [CrossRef] [PubMed]

5. Halliwell, B.; Zhao, K.; Whiteman, M. The gastrointestinal tract: A major site of antioxidant action? Free Radic. Res. 2000, 33, 819-830. [CrossRef]

6. García-Nebot, M.-J.; Cilla, A.; Alegría, A.; Barberá, R. Caseinophosphopeptides exert partial and site-specific cytoprotection against $\mathrm{H}_{2} \mathrm{O}_{2}$-induced oxidative stress in Caco-2 cells. Food Chem. 2011, 129, 1495-1503. [CrossRef] 
7. Boots, A.-W.; Haenen, G.-R.-M.-M.; Bast, A. Health effects of quercetin: From antioxidant to nutraceutical. Eur. J. Pharmacol. 2008, 585, 325-337. [CrossRef] [PubMed]

8. Amakura, Y.; Yoshimura, A.; Yoshimura, M.; Yoshida, T. Isolation and Characterization of Phenolic Antioxidants from Plantago Herb. Molecules 2012, 17, 5459-5466. [CrossRef]

9. Beara, I.-N.; Lesjak, M.-M.; Jovin, E.-Đ.; Balog, K.-J.; Anackov, G.T.; Orcic, D.Z.; Mimica-Dukic, N.M. Plantain (Plantago L.) species as novel sources of flavonoid antioxidants. J. Agric. Food Chem. 2009, 57, 9268-9273. [CrossRef]

10. Lim, Y.; Lee, K.-W.; Kim, J.-Y.; Kwon, O. A beverage of Asiatic plantain extracts alleviated postprandial oxidative stress in overweight hyperlipidemic subjects challenged with a high-fat meal: A preliminary study. Nutr. Res. 2013, 33, 704-710. [CrossRef]

11. Carmona-Jiménez, Y.; García-Moreno, M.-V.; Igartuburu, J.-M.; Garcia, B.C. Simplification of the DPPH assay for estimating the antioxidant activity of wine and wine by-products. Food Chem. 2014, 165, 198-204. [CrossRef] [PubMed]

12. Mello, J.-C.; Guimaraes, N.; Gonzalez, M.; Paiva, J.-S.; Prieto, T.; Nascimento, O.-R.; Rodrigues, T. Hydroxyl scavenging activity accounts for differential antioxidant protection of Plantago major against oxidative toxicity in isolated rat liver mitochondria. J. Pharm. Pharmacol. 2012, 64, 1177-1187. [CrossRef] [PubMed]

13. Du, Z.L.; Yin, Z.Q.; Wang, L. Coumarins and flavonoids from leaves of Broussonetia papyrifera. Nat. Prod. Res. Dev. 2008, 4, 630-632.

14. Shenghua, L. Flavonoid constituents of whole plant of Kummerowia striata. Chin. Pharm. J. 2014, 49, 817-820.

15. Song, J.-L.; Gao, Y. Effects of methanolic extract form Fuzhuan brick-tea on hydrogen peroxide-induced oxidative stress in human intestinal epithelial adenocarcinoma Caco-2 cells. Mol. Med. Rep. 2014, 9, 1061-1067. [CrossRef]

16. Zou, Y.; Wang, J.; Peng, J.; Wei, H. Oregano essential oil induces SOD1 and GSH expression through nrf2 activation and alleviates hydrogen Peroxide-Induced oxidative damage in IPEC-J2 cells. Oxid. Med. Cell. Longev. 2016, 2016, 5987113-5987183. [CrossRef]

17. Turktekin, M.; Konac, E.; Onen, H.-I.; Alp, E.; Yilmaz, A.; Menevse, S. Evaluation of the effects of the flavonoid apigenin on apoptotic pathway gene expression on the colon cancer cell line (HT29). J. Med. Food 2011, 14, 1107-1117. [CrossRef]

18. Hea, C.; Denga, J.; Hua, X.; Zhoua, S.; Wua, J.; Di, X.; Oteng, K.; Darkoa, Y.-H.-T.-T. Vitamin a inhibits the action of LPS on intestinal epithelial barrie function and tight junction proteins. Food Funct. 2019, 10, 1235-1242. [CrossRef]

19. Wang, N.; Wang, G.; Hao, J.; Ma, J.; Wang, Y.; Jiang, X.; Jiang, H. Curcumin ameliorates hydrogen Peroxide-Induced epithelial barrier disruption by upregulating heme oxygenase-1 expression in human intestinal epithelial cells. Digest. Dis. Sci. 2012, 57, 1792-1801. [CrossRef]

20. Storz, P. Reactive oxygen species in tumor progression. Front. Biosci. 2005, 10, 1881-1896. [CrossRef]

21. Wijeratne, S.-S.-K.; Cuppett, S.-L.; Schlegel, V. Hydrogen peroxide induced oxidative stress damage and antioxidant enzyme response in Caco-2 human colon cells. J. Agric. Food Chem. 2005, 53, 8768-8774. [CrossRef] [PubMed]

22. Chen, B.; Lu, Y.; Chen, Y.; Cheng, J. The role of Nrf2 in oxidative stress-induced endothelial injuries. J. Endocrinol. 2015, 225, R83-R99. [CrossRef]

23. Tkachev, V.-O.; Menshchikova, E.-B.; Zenkov, N.-K. Mechanism of the Nrf2/Keap1/ARE signaling system. Biochem. Mosc. 2011, 76, 407-422. [CrossRef] [PubMed]

24. Jung, W.-W. Protective effect of apigenin against oxidative stress-induced damage in osteoblastic cells. Int. J. Mol. Med. 2014, 33, 1327-1334. [CrossRef] [PubMed]

25. Patlevic, P.; Vaskova, J.; Svorc, P.-J.; Vasko, L.; Svorc, P. Reactive oxygen species and antioxidant defense in human gastrointestinal diseases. Integr. Med. Res. 2016, 5, 250-258. [CrossRef]

26. Couto, N.; Wood, J.; Barber, J. The role of glutathione reductase and related enzymes on cellular redox homoeostasis network. Free Radic. Biol. Med. 2016, 95, 27-42. [CrossRef]

27. Bachhawat, A.-K.; Yadav, S. The glutathione cycle: Glutathione metabolism beyond the $\gamma$-glutamyl cycle. IUBMB Life 2018, 70, 585-592. [CrossRef]

28. Shi, Y.; Kovacs-Nolan, J.; Jiang, B.; Tsao, R.; Mine, Y. Peptides derived from eggshell membrane improve antioxidant enzyme activity and glutathione synthesis against oxidative damage in Caco-2 cells. J. Funct. Foods 2014, 11, 571-580. [CrossRef] 
29. Brand-Williams, W.; Cuvelier, M.-E.; Berset, C. Use of a free radical method to evaluate antioxidant activity. LWT-Food Sci. Technol. 1995, 28, 25-30. [CrossRef]

30. Shao, Y.; Lei, Z.; Wolf, P.-G.; Gao, Y.; Guo, Y.; Zhang, B. Zinc Supplementation, via GPR39, Upregulates PKCᄃ to Protect Intestinal Barrier Integrity in Caco-2 Cells Challenged by Salmonella enterica Serovar Typhimurium. J. Nutr. 2017, 147, 1282-1289. [CrossRef]

31. Fernández-Blanco, C.; Font, G.; Ruiz, M. Oxidative DNA damage and disturbance of antioxidant capacity by alternariol in Caco-2 cells. Toxicol. Lett. 2015, 235, 61-66. [CrossRef] [PubMed]

Sample Availability: Samples of the isolated compounds are not available from the authors.

(C) 2020 by the authors. Licensee MDPI, Basel, Switzerland. This article is an open access article distributed under the terms and conditions of the Creative Commons Attribution (CC BY) license (http://creativecommons.org/licenses/by/4.0/). 